\title{
EFFECT DEGRADABLE PROTEIN LEVEL G/MJ METABOLIZABLE ENERGY THROUGH DIFFERENT STAGES OF LACTATION ON MILK YIELD AND COMPOSITION OF AWASSI EWES
}

\author{
O. D. M. Almallah \\ Assist. Prof.
}

Dept. of Animal production, College. of Agric. and Forestry , University of Mosul , Iraq. dromaralmallah@gmail.com

\section{ABSTRACT}

This study investigated the effect of feeding two levels of rumen degradable protein in the rations during different stages of lactation on milk yield and components, twenty four cross breed Awassi ewes (Turkish Awassi $\times$ Iraqi Awassi) were used with their single lambs after birth aged 3-5 years, ewes were divided into two groups with average body weights $66.00 \pm 2.32 \mathrm{~kg}$ and $67.10 \pm 2.62 \mathrm{~kg}$ respectively, first group was control fed adequate level of degradable protein (10 $\mathrm{g} / \mathrm{Mj}$ metabolizable energy) and second group fed high level of degradable protein (12.5 g / Mj metablizable energy), Lactation period had been divided into three stages (early, 1-50 day ), ( mid , 51-100 day) and (late, 101-150 day), ewes were fed twice daily with restricted amount $2 \mathrm{~kg}$ in the early and mid and $1.5 \mathrm{~kg}$ in late lactation . Results showed that feeding adequate level of rumen degradable protein led to significant $(\mathrm{P}<\mathbf{0 . 0 5}$ ) increase in milk yield $785 \mathrm{~g} /$ day and lactose $5.81 \%$ as compared with high level 619 g/day and $5.58 \%$ respectively, also milk yield decreased $(P<0.05)$ while milk fat increased $(P<0.05)$ with advance milk period. Blood parameters were not affected significantly by feeding degradable protein while serum glucose, total protein and albumin decreased $(\mathrm{P}<0.05)$ at late stage of milk production. Best results of interaction for rumen degradable protein and milk stages in milk yield and components yield were noted with feeding adequate level of rumen degradable protein in the early lactation.

Key words: Protein type, lactation periods, Ewes Performance.

الملاح

1320-1314:51:2020 -5جلة العلوم الزراعية العراقية

تأثير مستوى البروتين المتحلل غم/ميكا جول طاقة ايضية خلال مراحل ادرار الحليب المختلفة على انتاج الحليب ومكوناته

$$
\text { في النعاج العواسية }
$$

عمر ضياء محمد الملاح

استاذ مساعد

قسم الانتاج الحيواني/ كلية الزراعة والغابات / جامعة الموصل / العرلق .

المستخلص

توضح هذه الدراسة تأثير التظذية على مستويين من البروتين المتحلل في الكرش خلال مراحل ادرار الحليب المختلفة في انتاج الحليب ومكوناته، استخدم اريعة وعشرون نعجة عواسية مضربة (عواسي عراقي × عواسي تركي) مع مواليدها الفردية بعدة الولادة مباشرة اعمارها تراوحت بين 3-5 سنوات. قسمت النعاج الى مجموعتين معدل اوزانها 66,00 × 2,32 و 67,10 × 2,62 كفم على التوالي، المجموعة الاولى كانت السيطرة غذيت على عليقة احتوت مستوى كافي من البروتين المتحلل 10 غروم/ ميكا جول طاقة ايضية والمجموعة

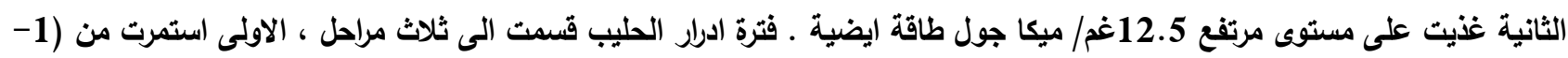

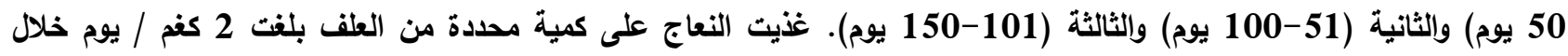

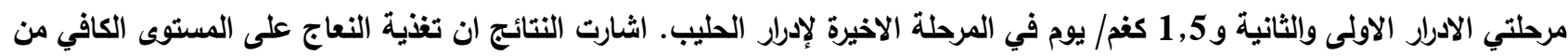

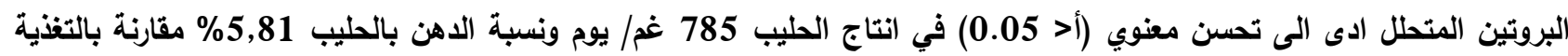

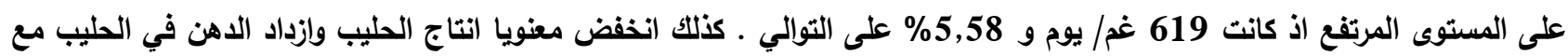

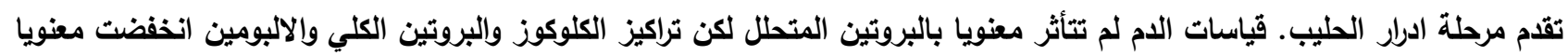

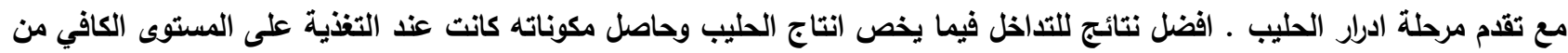
البروتين المتحلل خلال المرحلة الاولى للإدرار. الكلمات المفتاحية: نوع البروتين، فترة الادرار، الاداء الانتاجي للنعاج. 


\section{RESULTS AND DISCUSSION}

Results in Table 2 indicated that degradable protein level had a significant effect in milk yield, increasing degradable protein to 12.5 g/MJ metabolizable energy of diet significantly $(\mathrm{P}<0.05)$ lowered milk yield to $619 \mathrm{~g} /$ day compared adequate level of degradable protein $10 \mathrm{~g} / \mathrm{MJ}$ metabolizable energy of diet $785 \mathrm{~g} /$ day. Milk lactose increase ( $\mathrm{P}<0.05$ ) with feeding adequate level of rumen degradable protein $5.81 \%$ as compared high level of degradable protein $5.58 \%$, other milk components especially fat increase but not significantly when ewes fed with adequate level of rumen degradable protein. Also results were investigated significant decrease in milk yield as stage of lactation progresses 1273 , 538 and $295 \mathrm{~g} /$ day, with exception fat other milk components lactose, protein and solid not fat were not affected significantly with the progresses stage of lactation, milk fat percent increase in the mid stage of lactation $5.07 \%$ compared early lactation $4.25 \%$ and this increase was significant $(\mathrm{P}<0.05)$ in late stage of lactation $7.88 \%$, as a result milk energy increase $(\mathrm{P}<0.05)$ in late stage of lactation $1101 \mathrm{kcal} / \mathrm{kg}$ than first and mid stage of lactation 785 and $855 \mathrm{kcal} / \mathrm{kg}$. Data of interaction were investigated that with progress stage of lactation milk yield was higher with feeding adequate level of degradable protein as compared with high level . Milk lactose, protein and solid non-fat were increased when ewes fed adequate degradable protein $10 \mathrm{~g} / \mathrm{MJ}$ metabolizable energy as compared to ewes fed high level of degradable protein $12.5 \mathrm{~g} / \mathrm{MJ}$ metabolizable energy in late lactation. Mei-Chu et al., (20) showed significant decrease in milk yield and protein while milk fat increase as degradable protein increase in the ration of goat, Mikolyunas-Sandrock et al.,(22) founds significant decrease in milk yield but not in milk fat and protein as degradable protein increase in the ration of ewes from 12 to $14 \%$ of dry mater, also Saleh., (29) noted significant improve in milk yield and components with exception protein as degradable protein decrease in the ration of ewes, while (17) and (3) they did not fond significant effect to increase rumen degradable protein in ewes milk yield and components, this result were noted in similar studies in dairy cows $(9,11$, 18 and 23). on other hand Aljuwari., (4) found significant decrease in milk yield with progress lactation stage with negative correlation between milk yield and fat content , Guler et al., (16) noted that the significant decrease in ewes milk yield as lactation stage progress were not correlated with fat and total solid, Doosh et al., (12) noted that milk fat, lactose and total solid increase while protein unchanged from week1 to week 16 of lactation, Kuchtik et al., (19) observed that milk protein and fat increase significantly while lactose decrease with advance lactation period, similar results were noted by Oravcova et al., (25) they observed significant increase in protein and fat content as milk stage,Mikolayunas et al., (21) report that milk yield was significantly higher in early lactation than late lactation, milk fat were unaffected but protein increased significantly in late lactation, Antunovi et al.,(7) were investigated that milk fat increase from 4.31 to $5.45 \%$ as lactation period increase from 20 to 100 day and protein and lactose content were unaffected . El-Tarabany et al.,(14) noted that milk yield decrease at rate $18.4 \%$ and $31.9 \%$ in mid and late stage of lactation compared with early stage, milk protein, fat and solid not fat un effected while lactose decreased in late as compared early and mid- lactation. Table 3 show that milk components yield of lactose , protein , fat and energy 44.94 , 30.17 , $41.17 \mathrm{~g} /$ day and $732 \mathrm{kcal} /$ day were significantly ( $\mathrm{P}<$ 0.05 ) higher when ewes fed adequate level of rumen degradable protein as compared to with high level of rumen degradable protein 35.06 , $23.66,28.75 \mathrm{~g} / \mathrm{day}$ and $550 \mathrm{kcal} / \mathrm{day}$ respectively, as well as it was decreased significantly $(\mathrm{P}<0.05)$ as milk period progress - Also noted from the interaction between protein degradability and milk period that milk components yield most values were decreased $(\mathrm{P}<0.05)$ as milk period progress and increase the level of rumen degradable protein, this differences in milk components are related to changes in milk yield. Blood parameters are given in Table 4 , the results were indicated that rumen degradable protein levels had no significant effect in serum glucose 70.97 and $70.00 \mathrm{mg} / \mathrm{dl}$, serum total protein 8.72 and 9.09 $\mathrm{g} / \mathrm{dl}$, serum albumin 3.94 and $3.86 \mathrm{~g} / \mathrm{dl}$ and 
serum urea 53.34 and $61.41 \mathrm{mg} / \mathrm{dl}$ respectively , regarding the effect of stage of lactation it was noted that serum glucose was higher $(\mathrm{P}<$ 0.05 ) in early stage of lactation $82.37 \mathrm{mg} / \mathrm{dl}$ as compared mid and late lactation 67.90 and $61.17 \mathrm{mg} / \mathrm{dl}$, serum total protein decreased with progresses milk period significantly $(\mathrm{P}<$ $0.05)$ in late lactation which were $10.04,9.84$ and $6.84 \mathrm{~g} / \mathrm{dl}$ respectively, serum albumin decrease $(\mathrm{P}<0.05)$ in mid lactation to 3.74 $\mathrm{g} / \mathrm{dl}$ and in late lactation to $3.50 \mathrm{~g} / \mathrm{dl}$ than in early lactation $4.44 \mathrm{~g} / \mathrm{dl}$, blood urea unaffected significantly through stages of lactation although there is trend to the increase blood urea in mid lactation as compared early and late lactation period . Data of interaction showed no significant effect of degradable protein within each stage of lactation with exception of urea concentration in early lactation it was decreased $(\mathrm{P}<0.05)$ in ewe that fed with adequate level of degradable protein $45.79 \mathrm{mg} / \mathrm{dl}$ as compared to high level 61.77 mg/dl. Salih., (30) fed Awassi ewes with low or high level of degradable protein and found that serum glucose was not affected while total protein significantly decreased with lowering degradable protein intake. Also AlKass et al., (5) did not found effect to the different levels of degradable to undegradable protein in serum total protein, albumin and glucose with except urea that increased significantly with decrease degradable protein in the ration, Gomes et al., (15) mention that increase degradable protein intake led to significant increase in blood urea without effect in glucose concentration. Kaufman et al., (18) found no significant effect in serum glucose as a result in increased degradable protein ratio in the ration in early lactation dairy cow . On other hand Piccione et al., (26) found no effect of lactation stage in serum total protein and albumin in ewes. Antunovi et al., (7) report that serum glucose and total protein were not affected but the blood urea increased significant as advanced days of milk in ewes , El-Tarabany et al., (14) report that serum glucose and total protein were greater in early and mid than late lactation.

Table.2. Effect of rumen degradable protein and stage of lactation in milk yield and composition.

\begin{tabular}{|c|c|c|c|c|c|c|}
\hline \multicolumn{7}{|c|}{ Effect of rumen degradable protein } \\
\hline & $\begin{array}{c}\text { Milk Yield } \\
\text { g/d }\end{array}$ & $\begin{array}{c}\text { Lactose } \\
\%\end{array}$ & $\begin{array}{l}\text { Protein } \\
\%\end{array}$ & $\begin{array}{l}\text { Fat } \\
\%\end{array}$ & $\begin{array}{l}\text { SNF } \\
\%\end{array}$ & $\begin{array}{l}\text { Energy } \\
\text { kcal/kg }\end{array}$ \\
\hline Adequate & $785 \pm$ & $5.81 \pm$ & $3.90 \pm$ & $5.89 \pm$ & $\mathbf{1 0 . 5 5} \pm$ & $933 \pm$ \\
\hline deg. protein & 101.78 a & 0.07 a & 0.05 & 0.48 & 0.13 & 43.24 \\
\hline $\begin{array}{c}\text { High } \\
\text { deg. protein }\end{array}$ & $\begin{array}{c}619 \pm \\
106.22 b\end{array}$ & $\begin{array}{l}5.58 \pm \\
0.09 \text { b }\end{array}$ & $\begin{array}{c}3.79 \pm \\
0.06\end{array}$ & $\begin{array}{c}5.49 \pm \\
0.46\end{array}$ & $\begin{array}{c}10.30 \pm \\
0.15\end{array}$ & $\begin{array}{l}889 \pm \\
41.22\end{array}$ \\
\hline \multicolumn{7}{|c|}{ Effect of Lactation stages } \\
\hline Early & $\begin{array}{c}1273 \pm \\
51.27 \text { a }\end{array}$ & $\begin{array}{c}5.61 \pm \\
0.05\end{array}$ & $\begin{array}{c}3.76 \pm \\
0.03\end{array}$ & $\begin{array}{l}4.25 \pm \\
0.15 \text { b }\end{array}$ & $\begin{array}{c}10.23 \pm \\
0.10\end{array}$ & $\begin{array}{c}785 \pm \\
16.65 \mathrm{~b}\end{array}$ \\
\hline Mid & $\begin{array}{c}538 \pm \\
30.14 \text { b }\end{array}$ & $\begin{array}{c}5.81 \pm \\
0.08\end{array}$ & $\begin{array}{c}3.92 \pm \\
0.05\end{array}$ & $\begin{array}{l}5.07 \pm \\
0.37 \text { b }\end{array}$ & $\begin{array}{c}10.62 \pm \\
0.14\end{array}$ & $\begin{array}{c}854 \pm \\
33.69 \text { b }\end{array}$ \\
\hline Late & $\begin{array}{c}295 \pm \\
36.69 \text { c }\end{array}$ & $\begin{array}{c}5.67 \pm \\
0.16\end{array}$ & $\begin{array}{c}3.86 \pm \\
\mathbf{0 . 1 0}\end{array}$ & $\begin{array}{l}7.88 \pm \\
0.48 \text { a }\end{array}$ & $\begin{array}{c}10.44 \pm \\
0.24\end{array}$ & $\begin{array}{c}1101 \pm \\
45.18 \mathrm{a}\end{array}$ \\
\hline \multicolumn{7}{|c|}{ Effect of interaction } \\
\hline Adequate $\times$ Early & $\begin{array}{r}1337 \pm \\
89.51 \text { a }\end{array}$ & $\begin{array}{c}5.57 \pm \\
0.10 \text { bc }\end{array}$ & $\begin{array}{c}3.75 \pm \\
0.06 \text { bc }\end{array}$ & $\begin{array}{l}4.46 \pm \\
0.07 \text { b }\end{array}$ & $\begin{array}{l}10.15 \pm \\
0.18 \text { bc }\end{array}$ & $\begin{array}{c}807 \pm \\
20.45 \text { b }\end{array}$ \\
\hline Adequate $\times$ Mid & $\begin{array}{c}611 \pm \\
38.42 \text { b }\end{array}$ & $\begin{array}{c}5.82 \pm \\
0.12 \text { ab }\end{array}$ & $\begin{array}{c}3.87 \pm \\
0.07 \text { abc }\end{array}$ & $\begin{array}{l}5.24 \pm \\
0.56 \text { b }\end{array}$ & $\begin{array}{c}10.52 \pm \\
0.21 \text { abc }\end{array}$ & $\begin{array}{c}867 \pm \\
50.82 \text { b }\end{array}$ \\
\hline Adequate $\times$ Late & $\begin{array}{c}407 \pm \\
27.21 \mathrm{c}\end{array}$ & $\begin{array}{l}6.04 \pm \\
0.07 \text { a }\end{array}$ & $\begin{array}{l}4.10 \pm \\
0.06 \text { a }\end{array}$ & $\begin{array}{l}8.25 \pm \\
0.65 \text { a }\end{array}$ & $\begin{array}{l}11.00 \pm \\
0.14 \text { a }\end{array}$ & $\begin{array}{c}1140 \pm \\
59.13 \text { a }\end{array}$ \\
\hline high $\times$ Early & $\begin{array}{c}1210 \pm \\
44.08 \text { a }\end{array}$ & $\begin{array}{c}5.65 \pm \\
0.05 \text { abc }\end{array}$ & $\begin{array}{c}3.78 \pm \\
0.03 \text { bc }\end{array}$ & $\begin{array}{l}4.04 \pm \\
0.28 b\end{array}$ & $\begin{array}{l}10.31 \pm \\
0.09 \text { bc }\end{array}$ & $\begin{array}{c}763 \pm \\
24.58 \text { b }\end{array}$ \\
\hline High $\times$ Mid & $\begin{array}{c}465 \pm \\
19.43 \mathrm{c}\end{array}$ & $\begin{array}{c}5.80 \pm \\
0.11 \text { ab }\end{array}$ & $\begin{array}{c}3.98 \pm \\
0.07 \text { ab }\end{array}$ & $\begin{array}{l}4.91 \pm \\
0.52 \mathrm{~b}\end{array}$ & $\begin{array}{l}10.72 \pm \\
0.21 \text { ab }\end{array}$ & $\begin{array}{c}841 \pm \\
48.43 \text { b }\end{array}$ \\
\hline High $\times$ Late & $\begin{array}{c}182 \pm \\
11.53 \mathrm{~d}\end{array}$ & $\begin{array}{l}5.30 \pm \\
0.23 \text { c }\end{array}$ & $\begin{array}{l}3.62 \pm \\
0.14 \text { c }\end{array}$ & $\begin{array}{l}7.50 \pm \\
0.73 \text { a }\end{array}$ & $\begin{array}{l}9.88 \pm \\
0.33 \text { c }\end{array}$ & $\begin{array}{c}1060 \pm \\
69.67 \text { a }\end{array}$ \\
\hline
\end{tabular}

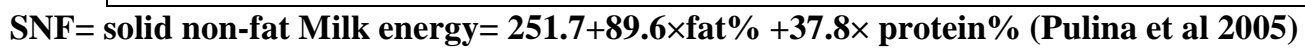

Values in the same column with different superscripts differ $(p<0.05)$. 
Table. 3. Effect of rumen degradable protein and stage of lactation in milk components yield

\begin{tabular}{|c|c|c|c|c|}
\hline \multicolumn{5}{|c|}{ Effect of rumen degradable protein } \\
\hline Adequate & $\begin{array}{l}\text { Lactose } \\
\text { g/day }\end{array}$ & $\begin{array}{l}\text { Protein } \\
\text { g/day }\end{array}$ & $\begin{array}{l}\text { Fat } \\
\text { g/day }\end{array}$ & $\begin{array}{c}\text { Energy } \\
\text { Kcal/day }\end{array}$ \\
\hline deg. protein & $44.94 \pm 5.55 \mathrm{a}$ & $30.17 \pm 3.73$ a & $41.17 \pm 3.78$ a & $732 \pm 70.54$ a \\
\hline $\begin{array}{c}\text { High } \\
\text { deg. protein }\end{array}$ & $35.06 \pm 6.03 \mathrm{~b}$ & $23.66 \pm 4.03 \mathrm{~b}$ & $28.75 \pm 4.14 b$ & $550 \pm 78.22 \mathrm{~b}$ \\
\hline \multicolumn{5}{|c|}{ Effect of Lactation stages } \\
\hline Early & $71.49 \pm 3.00$ a & $47.95 \pm 2.06$ a & $55.35 \pm 3.44$ a & $1001 \pm 46.66 \mathrm{a}$ \\
\hline Mid & $31.30 \pm 1.86 \mathrm{~b}$ & $21.10 \pm 1.21 b$ & $26.02 \pm 2.03 b$ & $459 \pm 28.10 \mathrm{~b}$ \\
\hline \multicolumn{5}{|c|}{ Effect of interaction } \\
\hline Adequate $\times$ Early & $74.59 \pm 5.50$ a & $50.13 \pm 3.66$ a & $3.23 \pm 3.23$ a & $1074 \pm 60.83 a$ \\
\hline Adequate $\times$ Mid & $35.58 \pm 2.42 \mathrm{~b}$ & $23.65 \pm 1.69$ b & $29.03 \pm 2.69 \mathrm{~cd}$ & $525 \pm 29.03 \mathrm{c}$ \\
\hline Adequate $\times$ Late & $24.67 \pm 1.73$ c & $16.74 \pm 1.23 \mathrm{c}$ & $33.15 \pm 2.37 \mathrm{c}$ & $460 \pm 26.67 \mathrm{~cd}$ \\
\hline high $\times$ Early & $68.40 \pm 2.34$ a & $45.78 \pm 1.86$ a & $49.43 \pm 5.25$ b & $927 \pm 60.88 \mathrm{~b}$ \\
\hline High $\times$ Mid & $27.03 \pm 1.46 \mathrm{c}$ & $18.54 \pm 0.99$ bc & $22.69 \pm 2.69 \mathrm{de}$ & $392 \pm 29.45 \mathrm{~d}$ \\
\hline High $\times$ Late & $9.75 \pm 0.68 \mathrm{~d}$ & $6.68 \pm 1.82 \mathrm{~d}$ & $13.86 \pm 1.82 \mathrm{e}$ & $194 \pm 20.36 \mathrm{c}$ \\
\hline
\end{tabular}

Values in the same column with different superscripts differ $(p<0.05)$.

Table.4. Effect of rumen degradable protein and stage of lactation in some biochemical blood parameters.

\begin{tabular}{|c|c|c|c|c|}
\hline \multicolumn{5}{|c|}{ Effect of rumen degradable protein } \\
\hline Adequate & $\begin{array}{c}\text { Glucose } \\
\mathrm{mg} / \mathrm{dl}\end{array}$ & $\begin{array}{c}\text { Total protein } \\
\text { g/dl }\end{array}$ & $\begin{array}{l}\text { Albumin } \\
\text { g/dl }\end{array}$ & $\begin{array}{l}\text { Urea } \\
\mathrm{mg} / \mathrm{dl}\end{array}$ \\
\hline deg. protein & $70.97 \pm 4.45$ & $8.72 \pm 0.57$ & $3.94 \pm 0.19$ & $53.34 \pm 2.77$ \\
\hline $\begin{array}{l}\text { High } \\
\text { deg Protein }\end{array}$ & $70.00 \pm 3.92$ & $9.09 \pm 0.44$ & $3.86 \pm 0.12$ & $61.41 \pm 2.84$ \\
\hline \multicolumn{5}{|c|}{ Effect of Lactation stages } \\
\hline Early & $82.37 \pm 5.05$ a & $10.04 \pm 0.45 a$ & $4.44 \pm 0.21 \mathrm{a}$ & $53.78 \pm 7.83$ \\
\hline Mid & $67.90 \pm 4.33 \mathrm{~b}$ & $9.84 \pm 0.30 \quad \mathrm{a}$ & $3.74 \pm 0.09 \mathrm{~b}$ & $61.59 \pm 3.78$ \\
\hline Late & $61.17 \pm 2.30 \mathrm{~b}$ & $6.84 \pm 0.20 \quad b$ & $3.50 \pm 0.05 \mathrm{~b}$ & $56.76 \pm 2.75$ \\
\hline \multicolumn{5}{|c|}{ Effect of interaction } \\
\hline Adequate $\times$ Early & $80.87 \pm 9.64$ ab & $9.74 \pm 0.94 a$ & $4.60 \pm 0.40 \mathrm{a}$ & $45.79 \pm 2.23 \mathrm{~b}$ \\
\hline Adequate $\times$ Mid & $71.90 \pm 7.10 \mathrm{abc}$ & $9.93 \pm 0.74 a$ & $3.79 \pm 0.04$ bc & $58.17 \pm 7.12$ ab \\
\hline Adequate $\times$ Late & $60.14 \pm 1.54 \mathrm{c}$ & $6.50 \pm 0.25 b$ & $3.39 \pm 0.03 \mathrm{c}$ & $55.87 \pm 3.23$ ab \\
\hline high $\times$ Early & $83.87 \pm 4.94$ a & $10.33 \pm 0.17$ a & $4.28 \pm 0.20 \mathrm{ab}$ & $61.77 \pm 3.23$ a \\
\hline High $\times$ Mid & $63.91 \pm 5.14$ bc & $9.75 \pm 0.46 \mathrm{a}$ & $3.70 \pm 0.19 b c$ & $64.81 \pm 3.01$ a \\
\hline High $\times$ Late & $62.20 \pm 4.66 \mathrm{bc}$ & $7.19 \pm 0.22 \mathrm{~b}$ & $3.61 \pm 0.05 c$ & $57.65 \pm 4.93 \mathrm{ab}$ \\
\hline
\end{tabular}

Values in the same column with different superscripts differ $(\mathbf{p}<0.05)$.

In conclusion feeding high level of degradable protein or the increase of degradable protein intake had a detrimental effect in milk yield and this may be due to the its effect on energy utilization and udder health and this may be expected from the fast decline in milk yield in the third stage of lactation, also it is observed a negative correlation between milk yield and fat content, with a clear trend to decrease serum glucose and proteins with progress lactation stage .

\section{REFERENCES}

1.Abd-Elrahman, E. M. ; G. E. Mohmed and H. K. Elsayed. 2014. Effect of lactation stages on some blood serum biochemical parameters and milk production in dairy cows. Assiut Vet. Med. Journal. 60(142):83-88

2.Al-Khawaja, A. K. ; E. A. Al-Bayati and S. A. Matti. 1978. Chemical Composition and
Nutritional Value of Iraqi Feed Materials. Ministry of Agriculture and Agrarian Reform, General Directorate of Animal Resources

3.AlJouwari, W. A. 2013. Effect of Ration Contented of Highly Degradable Starch and Nitrogenous Compounds on Milk Yield, Composition and Some Blood Parameters in Ewes. M.Sc. Thesis College of Agriculture and Forestry, Mosul , Iraq. Ppi. 60

4.AlJuwari, M. F. 2005. The Use of Test-Day For milk Yield to Select Awassi Ewes . M.Sc. Thesis College of Agriculture and Forestry , Mosul , Iraq. Ppi. 27

5.AlKass, J. E. ;K. N. Dosky and E. T. Buti. 2014. Influence of varying levels of rumen degradable to undegradable protein on milk yield, composition and some blood parameters of Karadi ewes. Mesopotamia J. of Agri. 42(2):277-278 
6.Antunovi, Z. ; J. Novoselec ; M. Speranda ; M. Vegara ; V. Pavic ; B. Mioc ; and M. Djidara . 2011. Changes in biochemical and hematological parameters and metabolic hormones in Tsigai ewe blood in the first third of lactation . Archive Tierzucht. 54:535-545.

7.Antunovi, Z. ; J. Novoselec ; M. Speranda ; Z. Steiner; S. Cavar ; N. Pavlovic ; K. Lendi ; B. Mioc ; N. Pacinovski and Z. Klir. 2017. Monitoring of blood metabolic profile and milk quality of ewes during lactation in organic farming. Mljekarstov. 67(4):243-252

8.AOAC.2002. Official Method of Analysis. $17^{\text {th }}$ ed.( Association of Official Analytic Chemists), Washington, DC

9.Bahrami-Yekdangi, M. ; C. R. Chorbani ; M. Khorvash ; M. A. Khan and M. H. Ghaffari. 2016. Reducing crud protein and rumen degradable protein with a constant concentration of rumen undegradable protein in the diet of dairy cow : production performance, nutrient digestibility, nitrogen efficiency and blood metabolites . J. Anim. Sci. 94:718-725

10.Brinez, W. J. ; E. Valbueno ; G. Castro ; A. Tavur ; R. J. Ruis and R. Roman. 2003. Effect of breed, season, lactation stage and purity number on composition of raw milk of crossbreed cows . Revista Cietifice 13(6):490498

11.Cyriac, J. ; A. G. Rius; M. L. McGilliard ; R. E. Pearson ; B. J. Bequette and M. D. Hanigan. 2008. lactation performance of midlactation dairy cows fed ruminally degradable protein at concentrations lower than national research council recommendations. J. Dairy Sci. 91:4704-4713

12.Doosh, K. S. ;A. M. Salih and N. N. AlAnbari. 2008. Milk composition of awassi sheep and their crosses with d'aman. Iraqi Journal of Agriculture Sciences. 39(6):142150

13.Duncan, C. B. 1955. Multiple rang and Mutiple "F" test. Biometric $11: 1-12$

14.El-Tarabany, M. S. ; A. A. El-Tarabany ; and E. M. Roushdy. 2018. Impact of lactation stage on milk composition and blood biochemical and hematological parameters of dairy baladi goats. Saudi J. of Bio. Sci. 25:1632-1638

15.Gomes, R. S. ; T. S. De Olivera ; J. C. Pereira ; R. A. Vieira ; D. S. Henrique ; A. M.
Fernandes and F. P. Leonel. 2016. Performance and metabolite profit of dairy cows fed tropical grasses and concentrates containing crud protein with low or high degradability . Revista Brasileira de Zootecnia. 45(9):572-580

16.Guler, Z. ; M. Kestin ; T. Masatcioglu ; S. Gul and O. Biçer . 2007. Effect of breed and lactation period on some characteristics and free fatty acid composition of raw milk from Damascus goat and German faw $x$ hair goat B1 crossbreeds. Turk. J. Vet. Anim. Sci. 31(5):347-354

17.Kassem, M. M. 2010. Effect of using barley grain and weight bran of reduced ruminal degradability on milk production and composition by Awassi ewes under pasture condition . Jordon J. of Agric. Sci. 6(2):295306.

18.Kaufman,J. D. ; K. G. Pohler ; J. T. Mulliniks and A. G. Rius. 2018. Lowering rumen degradable and rumen undegradable protein improved amino acid metabolism and energy utilization in lactating dairy cows exposed to heat . J. Dairy Sci. 101:386-395

19.Kuchtik, J.. ;K. Sustova ; T. Urban and D. Zapleta. 2008. The effect of stage of lactation on milk composition, its properties and the quality of rennet curdling in east Friesian ewes. Cezch J. Anim. Sci. 52(2):55-63.

20.Mei-Chu, L. ; S. Hwang and W. Chiou. 2001. Application of rumen undegradable protein on early lactation dairy goat. AsianAustralian J. Anim. Sci. 14(11):1549-1554

21.Mikolayunas, C.; D. L. Thomas ; K. A. Combs ; Y. M. Berger and S. R. Eckerman. 2008. Effect of supplementation and stage of lactation on performance of grazing dairy ewes. J. Dairy Sci. 91:1477-1485

22.Mikolayunas-Sandrock, C.; L. E. Armentano; D. L. Thomas and Y. M. Berger . 2009. Effect of protein degradability on milk production of dairy ewes. J. Dairy. Sci. 92 :4507-4513

23.NRC. 2001. Nutrient Requirements of Dairy Cattle. National Academy press. Washington, DC. Ppi 283

24.NRC. 2007. Nutrient Requirements of Small Ruminants. National Academy of Sciences. Washington, DC.Ppi. 442

25.Oravcova, M. ;M. Margetin and V. Tancin. 2015. The effect of stage of lactation on daily 
milk yield and milk fat and protein content in Tsigai and improved valachian ewes. Mlyekarstvo. 65(1):48-56

26.Piccione. ; G. Caola ; G. Giannetto ; F. Grasso ; S. Calanni Runzo ; A. Zumbo and P. Pennisi . 2009. Selected biochemical serum parameters in ewes during pregnancy, postparturition, lactation and dry period . Animal Science Paper Report 27:321-330 27.Nudda .2005. Milk composition and feeding in the Italian dairy sheep. Italian Journal Animal Science. 4 ( Suppl 1 ) : 5-14 28.Rook, G. F. A. and P. C. Thomas. 1983. Nutritional and Physiology of Farm Animals. ed. 1. Longman Inc. New York. Ppi. 397 29.Saleh, M. N. 2009. Using Concentrate Feed Reduced Degradability on Feeding Sheep Effect on Reproductive and Performance .
Ph.D. Dissertation, College of Agriculture and Forestry , Mosul , Iraq. Ppi.76. 30.Salih, A. M. 2008. Effect of Different Levels of Protein in Formaldehyde Treated Ration on Performance and Some Biochemical Traits in Awassi Ewes. Ph.D. Dissertation, College of Agriculture and Forestry , Mosul, Iraq. Ppi. 66.

31.SAS. 2000. SAS system under P.C. Dos. SAS institute . Ine. Cary . NC 32.Tacoma, R. ; J. Field ; D. B. Ebenstein ; Y. W. Lam and S. L. Greenwood. 2017. Ratio of dietary rumen degradable protein to rumen undegradable protein effects nitrogen partitioning but does not affect the bovine milk proteome produced by mid-lactation Holstein dairy cow. J. Dairy Sci. 100(9): 